\title{
China's Footprints in Maldives: Concern for India?
}

\author{
S Y Surendra Kumar
}

\section{Abstract}

China has, in the recent decades, has consolidated its interests in the South Asian region. This change in China's foreign policy, from a focus on the North-East and South-East Asia, hints at an attempt to sustain China's own peaceful rise. India, on the other hand, has emphasised on a 'Look East' foreign policy in the recent times. Both India and China share an important diplomatic relationship with Maldives. However, China's growing influence in Maldives might be a serious strategic concern to India. This article is an exploratory study of the relationship that China shares with Maldives and its implications to India.

Keywords: China-Maldives relations, Politics, Military, Tourism.

\section{Introduction}

The way the foreign policy of China has evolved in recent decades to consolidate its interests could be an object lesson to other countries. Initially, China's Asian policy focused on North-East and South-East Asia. But in recent times, South Asia has gained tremendous importance in China's foreign policy, which currently aims to maintain and promote regional peace and stability and, in consequence, sustain China's own peaceful rise. Also, as India began to look eastward, China began to look southward to counter India's rise. In this context, South Asia constitutes an important region for China's strategic ambit, and Maldives is no different.

\footnotetext{
*Bangalore University, Bengaluru, India; surendrajnu@gmail.com
} 


\section{China-Maldives Relations: The Factors}

Maldives was not strategically vital for the colonial rulers. The archipelagic nation being poorly endowed with resources and an insalubrious climate, with its terrain being dotted with dangerous coral reefs. India was an exception in that, it commenced diplomatic ties with its South Asian neighbour quite early, and unlike China, India established its ties immediately after Maldives attained independence from British colonial rule in 1965. Thus, China ties with Maldives, began late, however it has deepened in recent times.

\section{Political and Military Ties}

China's relations with Maldives began slowly, but intensified with China's quest for global power. Maldives in October 1972 established formal relations with China, when the Chinese ambassador to Sri Lanka was concurrently accredited to Maldives. The two countries' bilateral relations improved with high-level visits between the two countries, which began with the Maldives Foreign Minister Jamil's visit to China in 1980, followed by President Maumoon Gayoom's visit in 1984. This trend intensified in the 1990s, as Maldives became vital for China's interest in providing safe passage to its merchant ships and accessing the sea lanes in the Indian Ocean. Since then, the relations have improved further, with bilateral high-level visits. The Maldives Foreign Minister and Defence and National Security Minister have regularly visited China. This has been reciprocated by Chinese Foreign Minister, Vice-Chairperson of the Standing Committee of the National People's Congress, Chairman of the Central Committee, General Chief of Staff of the PLA and Premier respectively in 1980 and 1990s.

In 2002 the two countries celebrated the 30th anniversary of the establishment of their bilateral diplomatic relations, with President Jiang Zemin and Foreign Minister Tang Jiaxuan exchanging congratulatory messages with President Gayoom and Foreign Minister Jameel, respectively. In September 2002, at the invitation of China's Central Military Commission, the Maldives State Minister of Defence and National Security visited China, which was the first official contact between the Chinese and Maldives 
armies. President Gayoom's visit in September 2006 further deepened the relations between the two countries. Maldives opened its embassy in Beijing in May 2009, and Ahmed Latheef was appointed as Maldives' first Ambassador to China. Party delegations from Maldives also visited China, to further ensure diplomatic cohesion. The visit by President Xi Jinping to Maldives in September 2014, in his first visit to South Asia, in a way indicated the balance-of-power dimension with India. President $\mathrm{Xi}$ was accompanied by a 100-member business delegation, demonstrating the economic focus of the visit.

In 2012, China and Maldives celebrated the 40th anniversary of the establishment of their formal bilateral ties, with Wu Bangguo, the Chairman of China's Standing Committee of the National People's Congress of China visiting Maldives. This was the first of its kind by a top Chinese legislator to the island. Bangguo emphasized during his visit that the relationship could be developed as a model between big and small nations. He also expressed the desire to open a Chinese Embassy in Maldives and promised to increase China's aid to Maldives to US \$15.4 million. Direct flights were announced to Maldives and scholarships were offered to Maldivian students in 2012 and 2013. In September 2013, a government delegation from Maldives attended the International Day of Peace Activities in China and the China-South Asia Peace and Development Forum. Political ties were further deepened with China opening its Embassy in Maldives in January 2014. It may be noted that China is the only non-South Asian country to set up an Embassy in Maldives, in order to cater for the needs of the large number of Chinese tourists visiting the archipelagic nation.

A military aid agreement was signed between the two countries in 2012. Initially, China's interest was to set up a military base in Maldives. But this objective has now taken a back seat with Sri Lanka forthcoming in meeting some of China's key maritime interests and with China not interested in antagonising the US and India, who are other security partners of Maldives. Nevertheless, there are reports that Beijing is still wooing Male to pre-empt a US move to set up a new military base in Maldives' southernmost island of Gan. 


\section{Trade, Investment and Aid}

Economic and technological cooperation between China and Maldives has also been growing over the years since 1981. Direct trade between the two countries has been growing since 1982, reaching US \$2.977 million in 2002, of which Maldives exports were worth just US $\$ 2000$, the imports from China being mainly rice and consumer goods. Bilateral trade went up to US \$64 million in 2010, a rise of 56 per cent from 2009. With China providing concessional loans and investments to Maldives particularly in the fisheries sector and aquatic products, bilateral trade increased to US \$98 million in 2013 and US \$104 in 2014. In recent times, China is an emerging market for Maldives marine products like yellow-fin tuna and sea cucumber. Furthermore, the two countries have initiated a feasibility study on free trade agreement (FTA) in February 2015. According to the Maldives Minister for Fisheries and Agriculture, "The biggest advantage of the free trade will go towards fishermen. With the free trade, 12 per cent export duty will be gone, thus the 12 per cent becomes profit for fishermen".

There are a number of reasons for the growing bilateral economic ties, like several bilateral agreements and Memorandums of Understanding (MOUs), such as the Agreements on Economic and Technical Cooperation, Mutual Exemption of Visas and Visa Fees, on Education Cooperation, on Cultural Cooperation and various other important areas of mutual interest. These agreements have increased the number of Maldivian people visiting China for trade and business, in a way making China a most preferred destination for Maldivian traders. Apart from this, Maldives' liberal trade regime, increase in the number of Chinese tourists to Maldives, and China offering its state owned companies preferential loans to enable them to contribute to infrastructure building in the island, have strengthened the bilateral economic ties. The preference for China for Maldives' economic growth was well articulated by President Abdulla Yameen in November 2014 in that "Western colonial powers'" economic cooperation with China does not challenge Maldives' Islamic identity.

On the investment front, Beijing is actively involved in several renewable energy projects, tourism and telecommunication sectors in Maldives. The Chinese investment increased from 1985 onwards. 
By the end of 2001, the accumulated volume for Chinese companies contracted projects in Maldives reached $\$ 46.37$ million, with their turnover reaching $\$ 40$ million. The projects included a 1000 Housing Units Project in Hulhumale, the National Museum, housing for the Ministry of Culture and Heritage, roads, and drainage systems in Male. Significant major Chinese investments in Maldives include the bridge project connecting the airport and the capital. This has helped the archipelagic nation's tourism by ensuring that 30 to 40 per cent of the tourists are Chinese. To attract more investment and trade from China, Maldives has set up an office in Kunming, China.

Chinese investment in Maldives got a boost with Vice President Mohamed Jameel Ahmed visiting China in June 2014, followed by President Xi Jinping's visit. The two countries agreed to cooperate on developing Special Economic Zones (SEZ) and construction of harbours and bunkering facilities. The contract to expand Male airport was given to the Beijing Urban Construction Group after the Maldivian government cancelled a \$511 million deal with India's GMR Infrastructure two years earlier. When India protested this development, the Maldivian government emphasized that the Chinese firm does not have the right to run the airport for security reasons. An agreement has also been signed for the Male-Hulhule bridge, connecting the capital with its international airport. President Xi Jinping said in Male that he hoped that the bridge would be named China-Maldives Friendship Bridge.

In a significant move, on 22 July 2015, the Maldivian Parliament (Majlis) amended the constitution and approved by 70 votes (14 against) foreign ownership of land in the country, which many argue will be beneficial to China. Members of Parliament voting against the move said that allowing investment of more than $\$ 1$ billion could be used by China for its military expansion in the Indian Ocean region and would be detrimental to Maldivian national security interests. India also expressed its concern. But the Maldivian government argued that the bill was intended to strengthen Maldives' economic ties with China, rather than military ties. It may be noted, however, that if China's level of economic activity in Maldives increases exponentially, China may 
usurp India's advantage of being Maldives' third-largest trading partner.

Over the decades, Chinese aid and investment to Maldives have also deepened the economic ties. China's aid to Maldives in the 1970s was RMB74.7875 million. As noted earlier, Beijing, as a part of its aid programme, constructed a building to house the Maldives Ministry of Foreign Affairs, a National Museum, and is involved in the 1000 Housing Units Project. President Abdulla Yameen visited China in August 2014 and secured a \$16 million grant aid from China, which is expected to cover the costs partly of the MaléHulhule Bridge and other projects. China also provided emergency aid in December 2014 when Male's sewage treatment plant suffered a fire, leaving some 100,000 people without access to safe drinking water. It sent nearly 700 tons of fresh water and a Chinese Navy submarine rescue ship named Changxing, which could produce over 70 tons of desalted water every day. Hence trade, investment and aid over the years have transformed the bilateral ties, for the benefit of both the countries.

\section{Tourism}

The tourism industry accounts for about 70 per cent of Maldives' GDP, both direct and indirect via transportation, communication, and construction sectors. Maldives attracts a million tourists annually, of which Chinese tourists numbered 35,000 in 2008-9, and it increased to 363,626 in 2014, which accounted for one-third of arrivals, with 30 per cent market share. Boosting the Chinese arrivals are, besides the resplendent beauty of the archipelago, direct flights from Beijing, Shanghai, Guangzhou, Kunming, Chengdu, Chongqing and Hong Kong to Maldives. Chinese companies are also involved in promoting tourism in Maldives like China Union Pay (CUP), which has begun cash withdrawal services for cardholders in 95 per cent of ATM in Maldives after entering into partnership with Maldives' biggest bank in March 2010. Apart from this, a joint venture has been initiated between the two countries to expand tourism. For example, China's Guandong Beta Ocean and a Maldivian company were awarded Vaavu Atoll Kunaavashi to develop a five-star luxury resort with some 142 rooms. The Maldivian Tourism Ministry in May 2014 also signed 
an MOU with the state-owned China Machinery Engineering Corporation (CMEC) to develop Thaa Atoll Kalhufahalafushi as a resort. The Tourism Ministry has also launched the Visit Maldives Year 2016 campaign in its efforts to boost tourism to the country.

\section{Maritime Dimension}

Initially, China's objective in Maldives was to establish a military base in the archipelagic nation. The objective has, however, evolved in course of time leading to the following Xi-Yameen joint statement in September 2014:

"We have agreed to jointly build the 21st Century
Maritime Silk Road and take this opportunity to
enhance cooperation in the fields of maritime
economy, maritime security, ocean research,
environment protection, and disaster prevention.
We will also try to start some key projects that can
yield quick results, at an early date".

By endorsing MSR, Maldives seeks to promote itself as a vital trade-cum-transit port. China is encouraging this ambition by mapping the MSR through the Ihavandhippolhu Integrated Development Project, or iHavan which is in the northernmost atoll of Maldives. Thus, in recent times, the maritime dimension has gained greater significance in bilateral ties.

\section{Why is this happening?}

India has had strong historical, cultural, political and socioeconomic relations with Maldives. But in recent years Maldives has developed closer ties with China. Some of the reasons why Maldives prefers to deal with China are as follows:

a) Most of the Chinese projects are completed on time, unlike projects undertaken by Indian companies, such as the construction of the Indira Gandhi Memorial Hospital, which took an inordinately long time to complete; also, the quality of its construction is regarded to be poor. An important feature of India's aid diplomacy in South Asia is that while it is generous in extending largesse, project deadlines are rarely met. Also, the major part of India's aid goes towards 
building capacity and developing democratic institutions, whose outcome is difficult to evaluate. Apparently, land ownership in Maldives requires $\$ 1$ billion, where China has an advantage as its investment policy is friendly and less bureaucratic. In India, it would be difficult to get consensus on investing such a huge amount. According to Prof. Mahendra P. Lama, a South Asia analyst, China's political system allows it to go ahead with huge investment without concerning itself about domestic considerations, while in India, there are "domestic constituencies and angles to look into before starting a project in a foreign land". Also, according to Prof. Lama, India has only "conventional cultural, economic or diplomatic ties and has not been able to create and establish any strong Indian constituencies, and our policy towards Maldives has been heavily governmentcentric."

b) Human rights, democracy and rule of law play a vital role in determining India's relations with other countries, which is not the case with China. For example, when recently the Government of India protested against the ill treatment meted out to the former President Nasheed by the present Yameen government, the Maldivian Foreign Minister, Dunya Maumoon, remarked his government "will not take instructions from a foreign government [India]". Even earlier, the Indian government imposed travel restrictions and some economic sanctions in response to any move to destabilising democracy in the archipelagic nation. On the other hand, responding to the current political crisis in Maldives, the Chinese Foreign Ministry spokesperson Hong Lei remarked that the issue "is the domestic matter of the Maldives. ... China upholds the principle of noninterference in other countries' domestic affairs. We believe the Maldivian side can deal with its domestic affairs properly."

c) From time to time, China has come up with big selling ideas, which are being positively endorsed by the neighbouring countries. For example, the Maldives government has backed the Chinese-initiated Asian 
Infrastructure Investment Bank (AIIB). It has also responded positively to China's proposal for an FTA, which is now being pursued. Maldives has also joined China's ambitious MSR project and its 'One Belt One Road' Initiative. Thus, these Chinese initiatives have deepened the ties

d) On the occasion of the Maldives' 50th Independence Day (July 2015), Prime Minister Narendra Modi called Maldives a "valued partner" of India, but in reaction to the ill treatment meted out to former President Nasheed, he did not visit Maldives during his tour of Indian Ocean countries in August 2015. Even India's Foreign Secretary S. Jaishankar had to postpone his visit to Maldives during his SAARC Yatra for five months, indicating India's displeasure with Maldives' internal developments. Thus, all these aspects has influenced Maldives to engage with China, rather than with India.

\section{India's Response}

India, enjoys a strong historical, diplomatic and cultural ties with Maldives. However, bilateral ties have been challenged by China's footprint in Maldives. In this context, India's response has been to work on the strong historical foundations. New Delhi was among the first countries to establish diplomatic ties with Male. Although India always emphasizes on promoting democracy, it extended support to the authoritarian rule of Maldivian President Maumoon Gayoom for thirty years. India even sent its naval contingent to stymie an attempt to overthrow the Gayoom government by some Sri Lanka-based dissidents in 1988. Over the decades, New Delhi has been Male's Big Brother, the most influential foreign power in Maldives (and also in Bhutan). India-Maldives relations were so significant that Maldives even sought to purchase land in India for relocating its citizens in case they become environmental refugees as a result of climate change and rising sea levels. However, in recent times, Australia and the US have emerged as alternative options to Maldives.

The bilateral ties have also been a result of strong naval interaction between the two countries. According to the Indian Ministry of 
Defence (MOD), Maldives has more interaction with the Indian Navy and Coast Guard than any other country in the Indian Ocean. Over the decades, India has also helped Maldives set up its coastal surveillance capabilities. Recently, India was the first country to respond when Male's sewage treatment plant damaged, leaving many people without access to safe drinking water.

India is a major economic partner of Maldives. However, the relationship has faced hurdles after Maldives cancelled its contract with GMR (an Indian company) and gave the contract to a Chinese company for major investment in Male airport. The Indian government nevertheless continues to provide development aid and cooperation to Maldives without any conditionality to promote South-South cooperation, building solidarity and partnership between developing nations and good-neighbourhood policy. Generally, in the 1980s and 1990s India's aid to the archipelagic nation went towards building its long-term educational and health infrastructure. However, Indian aid intensified in 2007 in response to China's mounting interest in Maldives. In a significant move, the Indian government has hiked its aid allocation to Maldives from $\$ 4$ million in 2014 to $\$ 30$ million in 2015-16, indicating the enhanced priority it accords to Maldives. Although Maldives' share in India's total aid is just 2 per cent in 2015-16, its share has undergone a rough sevenfold increase from last year.

Both India and China are striving for maritime dominance in the Indian Ocean Region (IOR). China has been consolidating its commercial maritime interest in the region, while India has given importance to maintaining security. In July 2013 India signed a tripartite maritime security agreement with Sri Lanka and Maldives, to address common maritime security threats, challenges and also to enhance security primarily through cooperative measures. These involve joint cooperation on exclusive economic zone (EEZ) surveillance, search and rescue (SAR) operations, working on anti-piracy efforts, sharing and tracking of merchant vessels using new technology. All these would be addressed through Maritime Domain Awareness (MDA), Long Range Identification and Tracking (LRIT), Merchant Ship Information System (MSIS) and Automatic Identification system (AIS), SAR coordination including training, develop marine oil pollution 
response, and exchange of information on illegal maritime activities through channels of communication.

This agreement also caters to the needs of Maldives. Although sea areas between India and Maldives are not chokepoints, they are very wide and can be termed high seas strategic passage way, where the bulk of merchant traffic funnels in and out. The huge amount of traffic might result in accidents, pollution affecting the marine environment, and tourism and fishing industry, on which Maldives direly depends. Moreover, the Somali sea piracy has come close to the shores of Maldives and India. There have been a number of incidents of capturing Somali pirates in Maldives waters, exposing the vulnerability of this archipelagic nation. This aspect is addressed in the agreement. There is also the factor of terrorism launched from the sea. Overall, India's policy towards Maldives is guided by its good-neighbourhood policy and protecting its interest in IOR. This was well articulated by India's then Prime Minister Manmohan Singh in November 2011. When addressing the Maldivian Parliament he said, "This is our extended neighbourhood, we wish to work with the Maldives and other likeminded countries to ensure peace and prosperity in the IOR".

\section{Possibility of 'Chindia' (China+India) in Maldives}

Although in recent times both India and China are asserting their interest in Maldives, there are many areas where they can cooperate in their own interest and also in the interest of Maldives. For instance:

a) India can assist Maldives and other littoral states in their quest for economic growth and it can also offer to train their human resources and transfer technology. China in its turn can enhance its aid for infrastructure development. This will ensure that Maldives and other Indian Ocean nations will progress while maintaining good relations with both China and India. Both countries should realise that competition will only lead to the small states fearing both military hegemony and economic monopoly, which affects the growth of the region. 
b) Economic and energy security are prime strategic interests for India and China. The two countries are among the largest economies in the world and are keen to secure markets for exports, obtain raw materials, energy resources and enhance their international stature. Their economic resurgence is directly linked to their overseas trade and energy needs, most of which are transported by sea. India's imports and exports have reached $\$ 500$ billion already and may well touch $\$ 2$ trillion by 2020 . Also, India depends for 70 per cent of its fossil fuel on imports, whose figure is estimated to rise to 85 per cent by 2020. Many Indian security analysts believe that energy security will be India's prime strategic interest for the next 25 years. China also depends on overseas resources and energy supplies, especially oil and natural gas from the Persian Gulf and Africa. It is forecast that China's oil consumption would increase by 150 per cent by 2020 and its foreign supplies will be more than 75 per cent. In addition, both India and China want the protection of Sea Lanes of Communication (SLOCs), prevention of economic degradation and climate changes in the region. In this regard, Maldives becomes important as it sits along major sea lanes, including the East-West shipping route through which much of the Middle East oil headed for East Asia is transported. The archipelago is located just $340 \mathrm{~km}$ from the Indian coast.

c) Maldives told the United Nations in 1987 that a 2.01168 metre rise in sea level could submerge the whole country, and since then it has been highlighting the issue of climate change at all global forums. Both India and China are supporting the Maldives campaign on climate change. For example, when the US rejected the Kyoto Pact (1997) on global warming, China termed it as an "irresponsible decision". Both India and China have interacted with Maldives at successive international climate change negotiations, particularly at the Copenhagen summit, 2009. Both India and China can use new technology and support Maldives' cause at the global and regional levels. 
d) Maldives faces a potential rise in Islamic extremism. For instance, in 2010 some Maldivians were arrested in Pakistan for terrorist activity and training at camps in South Waziristan. This extremism could be a threat to Maldives and the region, affecting the interests of both India and China. There is also the possibility of terrorist groups trying to recruit members in Maldives, which will certainly affect its tourism and economy. Both India and China fear that especially in the context of rising religious radicalism in Maldives, anti-India terror groups will take root there and seek sanctuary in the many uninhabited islands of the archipelago. These anxieties have prompted India and China to intensify cooperation with successive Maldivian governments.

As regards balancing India and China in the context of Maldives, then President Nasheed said in May 2011: "I don't think we have to walk a tightrope. We are firstly a SAARC member country and China's friendship is about broader global interest rather than regional." In the interest of Maldives and the region, both India and China should work on a win-win situation through cooperation, rather than confrontation and competition, which will affect Maldives' growth and prosperity.

\section{References}

Bosley, D. (2014, September 15). Maldives gives airport contract to Chinese firm during Xi's visit. Reuters. Retrieved June 08, 2016, from http://in.reuters.com/ article/2014/09/15/china-maldivesidINKBN0HA1TS20140915

China, Maldives launch feasibility study on FTA. (2015, June 02). Xinhua. Retrieved July 11, 2016, from http://www.chinadaily.com.cn/ business/2015-02/06/ content_19507615.html

China and Maldives. (2015). Xinhua. Retrieved July 16, 2016, from www.fmprc.gov.cn/mfa_eng/wjb_663304/zzjg_663340/ yzs_663350/gjlb_663354/2737_663478/

Chinese Government Continues to Provide Emergency Assistance to the Maldives (Rep.). (2014, December 08). Retrieved June 15, 2016, from Ministry of Foreign Affairs of the People's Republic of China website: http://www.fmprc.gov.cn/mfa_eng/zxxx_662805/t1217941.shtml 
Das, P. (2011). Maritime power: Key to India's security interests. Policy Paper, 1.

GMR-Maldives spat: China behind scrapped GMR deal to extend footprint in Maldives? (2012, December 15). Economics Times. Retrieved July 17, 2016, from http://m.economictimes.com/news/ news-by-industry/transportation/airlines-/-aviation/gmr-maldivesspat-china-behind-scrapped-gmr-deal-to-extend-footprint-inmaldives/articleshow/17622309.cms

Hamid, I. H. (2014, December 22). Maldives backs new Chinese investment bank, pursues free trade deal. Minivan News. Retrieved June 15, 2016, from http://minivannewsarchive.com/ politics/ maldives-backs-new-chinese-investment-bank-pursues-free-tradedeal-91768\#sthash.Xb69wx5Q.dpuf

Hamid, I. (2015, June 11). Chinese investment in Maldives tourism 'expected to rise. Minivan News. Retrieved June 09, 2016, from http:/ / minivannewsarchive.com/ politics/chinese-investment-inmaldives-tourism-expected-to-rise-99406\#sthash.fcW6XbhC.dpuf

Holmes, J. R., Winner, A. C., \& Yoshihara, T. (2009). Indian naval strategy in the twenty-first century. Routledge.

Kahangama, I. (2014). India, Sri Lanka and Maldives: Tripartite Maritime Security Agreement and growing Chinese influence, in Bhattacherjee, Aparupa (eds.), The Maritime Great Game: Indian, China and US and the Indian Ocean, IPCS special focus, p.12

Karambelkar, A. (2011, June 22). Wu Bangguo's Visit to the Maldives. Indian Council of World Affairs. Retrieved July 19, 2016, from http://www.icwa.in/pdfs/vwpointwu.pdf

Kondapalli, Srikant (2014), "Maritime Silk Road: Increasing Chinese Inroads into the Maldives", Institute of Peace and Conflict Studies, No. 4735. Available at www.ipcs.org/ article/ china/maritime-silkroad-increasing-chinese-inroads-into-the-maldives-4735.html

Kumar, A. (2012). Chinese Engagement with the Maldives: Impact on Security Environment in the Indian Ocean Region. Strategic Analysis, 36(2), 276-289.

Maldives' tourism industry faces challenges as Chinese tourists decline. (2015, February 02). Xinhua. Retrieved June 21, 2016, from http://www.chinadaily.com.cn/travel/2015-

02/26/content_19660540.htm

Masood, A. (2015, July 07). C3S Paper No. 0003/2015. In India- MaldivesChina: Strategic Relations. Retrieved July 20, 2016, from http://www.c3sindia.org/ uncategorized/4753

Panda, A. (2015, February 26). India's Maldivian Headache. The Diplomat. Retrieved June 18, 2016, from http:/ / thediplomat.com/2015/02/indias-maldivian-headache/ 
Ramachandran, S. (2015, April 20). India's surging aid to Maldives points to its strategic location, Asia Times. Retrieved June 17, 2016, from http:/ / atimes.com/2015/04/indias-surging-aid-to-maldives-pointsto-its-strategic-location/

Raman, B. (2010, March 07). China in Maldives. In Chennai Centre for China Studies. Retrieved June 22, 2016, from Raman, B. (2010). “China in Maldives", C3S Paper, No.458, 7 March. Available at http:/ / www.c3sindia.org/maldives/1237

Sakhuja, V. (2014). India, Sri Lanka and Maldives: A Maritime troika leads the way Bhattacherjee, A. (eds.) The Maritime Great Game: Indian, China and US and the Indian Ocean, IPCS special focus, p.12

Samaranayake, N. (2012, March 01). Maldives: why the US and India should remain calm. PacNet, \#13. Retrieved June 16, 2016, from https:// www.csis.org/analysis/pacnet-13-maldives-why-us-andindia-should-remain-calm

Sharma, R. (2015, July 24). Maldives tweaks law on foreign freeholds, China likely to edge India on investment. Firstpost. Retrieved July 09, 2016, from http://www.firstpost.com/world/maldives-tweaks-lawon-foreign-freeholds-china-likely-to-edge-india-on-investment2362070.html

Variyar, M. (2015, July 27). Chinese 'Land Grab' in Maldives: How India Can Counter Beijing's Expanding Sphere of Influence. Chinese 'Land Grab' in Maldives: How India Can Counter Beijing's Expanding Sphere of Influence. Retrieved June 16, 2016, from http:/ / www.ibtimes.co.in/ maldives-land-ownership-why-indiashould-be-concerned-what-should-it-do-counter-china-640594 